\title{
Development of a Bio-PCR Protocol for the Detection of Xanthomonas arboricola pv. pruni
}

E. L. Ballard, School of Chemistry and Molecular Biosciences, The University of Queensland, Australia; R. G. Dietzgen, School of Chemistry and Molecular Biosciences, The University of Queensland, and Department of Employment, Economic Development and Innovation Agri-Science Queensland, Australia; L. I. Sly, School of Chemistry and Molecular Biosciences, The University of Queensland; C. Gouk, Department of Primary Industries, Victoria, Australia; C. Horlock, Department of Employment, Economic Development and Innovation, Agri-Science Queensland; and M. Fegan, School of Chemistry and Molecular Biosciences, The University of Queensland \begin{abstract}
Xanthomonas arboricola pv. pruni. Plant Dis. 95:1109-1115.
A real-time SYBR Green I assay was developed and evaluated as a biological and enzymatic polymerase chain reaction (Bio-PCR) protocol for the detection of Xanthomonas arboricola pv. pruni. Suppression subtractive hybridization was used to generate a $X$. arboricola $\mathrm{pv}$. pruni-specific subtracted DNA library, using $X$. arboricola pv. corylina as the driver strain. Primer pair 29F/R, designed from cloned sequence, showed no homology to GenBank sequences and amplified a 344-bp product in all $X$. arboricola pv. pruni isolates. Compared with other published $X$. arboricola pv. pruni primers, this primer pair was shown to be the only one capable of differentiating $X$. arboricola pv. pruni from all other $X$. arboricola pathovars. A real-time assay was
\end{abstract}

Abstract

Ballard, E. L., Dietzgen, R. G., Sly, L. I., Gouk, C., Horlock, C., and Fegan, M. 2011. Development of a Bio-PCR protocol for the detection of developed and shown to be capable of detecting less than $10 \mathrm{CFU}$ and $0.1 \mathrm{pg}$ of DNA. Epiphytic bacteria isolated from plum tissue was used to further evaluate the specificity of the assay. A Bio-PCR protocol, developed for field evaluation, confirmed $X$. arboricola pv. pruni isolation from asymptomatic and symptomatic plum tissue over a 9-week period between host flowering and the first appearance of leaf and fruit symptoms in an orchard. Dilution plating enabled $X$. arboricola pv. pruni numbers to be quantified, providing supportive evidence for the usefulness of the Bio-PCR protocol in plant pathology and quarantine surveillance.
Bacterial spot of stone fruit (Prunus spp.) affects nearly all of the major stone-fruit-growing regions of the world. It is becoming an increasing problem for the stone fruit industry, with recent reports indicating the spread of this disease $(5,11,16,18,20)$. The causal agent of bacterial spot, Xanthomonas arboricola pv. pruni, induces fruit and leaf lesions resulting in yield losses; however, it is the twig canker symptom which has long-term effects on the productivity of stone fruit trees (21). Control of this pathogen is currently limited to copper spray applications in areas already affected by the disease, and further spread has been restricted by strict quarantine regulation governed by the European and Mediterranean Plant Protection Organization (16).

Traditional plant pathology techniques are useful for the isolation and identification of $X$. arboricola pv. pruni from symptomatic and asymptomatic tissues. In recent years, significant novel facets in the life cycle of $X$. arboricola pv. pruni have been identified using these techniques. In Italy, $X$. arboricola pv. pruni was isolated from asymptomatic bud and leaf scars by culturing onto glucose-yeast-calcium-carbonate agar (GYCA), and indirect immunofluorescence staining was used to confirm and quantify $X$. arboricola pv. pruni (30). Survival of $X$. arboricola pv. pruni at the scar sites was later confirmed in Italy with studies involving the use of rifampicin- and chloramphenicol-resistant mutants (31). In South Carolina, United States, epiphytic X. arboricola pv. pruni

Corresponding author: E. L. Ballard,

E-mail: emma.ballard@uqconnect.edu.au

The sequence has been deposited in GenBank as accession number HN268887.

Accepted for publication 11 April 2011.

doi:10.1094/PDIS-09-10-0650

(C) 2011 The American Phytopathological Society was shown to be associated with asymptomatic twigs, leaves, buds, flowers, and fruit by culturing washings on Xanthomonas differential medium XPSM (25). The association of X. arboricola pv. pruni with a range of tissues suggests that improved control of this pathogen may be obtained with a greater understanding of the life cycle of $X$. arboricola pv. pruni by targeting treatments to crucial steps in its development. To facilitate such research, a molecular diagnostic test for $X$. arboricola pv. pruni is essential for specific and sensitive identification of this pathogen.

Development of a molecular diagnostic test for $X$. arboricola $\mathrm{pv}$. pruni has proven difficult in the past, due to the close genetic relationships between $X$. arboricola pathovars $(17,32)$. DNA:DNA homology studies indicated that $X$. arboricola pv. pruni shares $79 \%$ homology with the other $X$. arboricola pathovars: corylina, juglandis, populi, celebensis, and poinsettiicola type C (28). Two published primer pairs developed from repetitive extrogenic palindromic sequence and random amplified polymorphic DNA fragments are capable of detecting $X$. arboricola pv. pruni but also amplify $X$. arboricola pv. corylina and $X$. arboricola pv. juglandis $(17,32)$ (M. Pagani, personal communication).

Suppression subtractive hybridization $(\mathrm{SSH})$ has been shown to be useful for studies requiring differentiation between closely related bacteria $(3,6,27)$. The method involves hybridizing the DNA from two organisms, a tester (organism of interest) and a driver (closely related organism), followed by polymerase chain reaction (PCR) amplification of the unhybridized tester-specific subtracted DNA (4). The method has been especially useful for bacterial differentiation at the strain level and it has been successfully applied to other Xanthomonas spp. $(1,8,12)$. In this study, this method was used to identify $X$. arboricola pv. pruni-specific DNA from which an $\mathrm{X}$. arboricola pv. pruni-specific primer was developed. The tester DNA was obtained from pathovar type strain $X$. arboricola pv. pruni ICMP 51 and the driver DNA from pathovar type strain $X$. arboricola pv. corylina ICMP 5726. Although $X$. arboricola pvs. corylina and juglandis share a high degree of DNA:DNA homology (89\%) with X. arboricola pv. 
pruni, $X$. arboricola pv. corylina was chosen as the driver strain based on work previously conducted in our laboratory $(28,32)$. Zuli (32) examined repetitive extragenic palindromic sequences in $X$. arboricola pathovars and showed that the BOXAIR profile exhibited a high degree of similarity between pathovars pruni and corylina isolates compared with other pathovars, including juglandis.

Biological and enzymatic (Bio)-PCR involves culturing a pathogen prior to PCR amplification, making it a particularly useful method for increasing pathogen numbers to detectable levels in asymptomatic tissue and ensuring that only viable organisms are examined $(7,14,22,23)$. An additional benefit of this method is that copper, a known PCR inhibitor which is routinely used to control bacterial spot, is excluded from the PCR reaction (9). The aim of this study is to demonstrate the application of an X. arboricola $\mathrm{pv}$. pruni-specific Bio-PCR protocol in a field-based trial using both asymptomatic and symptomatic plant tissue.

\section{Materials and Methods}

Bacterial strains. The bacterial strains used during this study are listed in Table 1. All X. arboricola pv. pruni strains and X. arboricola pathovars, with the exception of X. arboricola pv. fragariae, were stored on Protect cyropreservation beads (Technical Consultant Services, Ltd., Heywood, Lancaster, UK) at $-80^{\circ} \mathrm{C}$. Two beads were placed onto GYCA plates, streaked, and incubated for 2 days at $28^{\circ} \mathrm{C}$. $X$. arboricola pv. fragariae was supplied as a freeze-dried specimen, which was rehydrated in $200 \mu \mathrm{l}$ of sterile water, streaked onto GYCA agar, and incubated for 2 days at $28^{\circ} \mathrm{C}$.

DNA extraction. DNA was extracted from 2-day-old cultures for all bacterial strains described in Table 1. For the SSH procedure, the tester DNA (pathovar type strain $X$. arboricola pv. pruni ICMP 51) and driver DNA (pathovar type strain $X$. arboricola pv. corylina ICMP 5726) were extracted using the ChargeSwitch gDNA Mini Bacteria Kit (Invitrogen, Carlsbad, CA) and quantified using the Biospec mini spectrophotometer (Shimadzu Biotech, Kyoto, Japan). For primer specificity and sensitivity testing, the Wizard Genomic DNA Purification Kit (Promega Corp., Madison, WI) "Isolation of genomic DNA from gram-positive and gramnegative bacteria" procedure was performed and DNA quantified by visual comparison with Hyperladder I (Bioline, London) following electrophoresis on a $2 \%$ (wt/vol) agarose gel in Tris-acetate-EDTA buffer and staining in ethidium bromide at $0.2 \mu \mathrm{g} \mathrm{ml} l^{-1}$.

SSH and identification of $X$. arboricola pv. pruni-specific DNA. SSH was performed using the BD PCR-Select Bacterial Genome Subtraction Kit (Clontech, Mountain View, CA) according to the manufacturer's recommendations. The secondary PCR products from the tester-specific subtracted DNA were purified using the QIAquick PCR Purification Kit (Qiagen, Valencia, CA), ligated into pGEM-T Easy (Promega Corp.), and the recombinant plasmids were transformed into XL10-Gold Ultracompetent cells (Stratagene, La Jolla, CA). Randomly selected clones were PCR amplified using both the M13 forward and reverse vector primers.

Table 1. Polymerase chain reaction (PCR) amplification of bacterial strains used in this study to evaluate the specificity of primer pair $29 \mathrm{~F} / \mathrm{R}$, designed from DNA sequence obtained by suppression subtractive hybridization for the specific detection of Xanthomonas arboricola pv. pruni, compared with other published primers

\begin{tabular}{|c|c|c|c|c|c|}
\hline \multirow[b]{2}{*}{ Isolates $^{\text {b }}$} & \multirow[b]{2}{*}{ Origin } & \multirow[b]{2}{*}{ Host plant ${ }^{c}$} & \multicolumn{3}{|c|}{ PCR amplification with primer pairs ${ }^{a}$} \\
\hline & & & 29F/R & Zuli & Pagani \\
\hline \multicolumn{6}{|c|}{ X. arboricola pv. pruni } \\
\hline $\operatorname{ICMP~} 51^{\mathrm{T}}$ & Mt. Albert, New Zealand & Japanese Plum & + & + & + \\
\hline ICMP 59 & United Kingdom & $\mathrm{n} / \mathrm{a}$ & + & + & + \\
\hline ICMP 60 & Argentina & Plum & + & + & + \\
\hline ICMP 62 & United States & Peach & + & + & - \\
\hline ICMP 4288 & Ontario, Canada & Peach & + & + & - \\
\hline ICMP 6677 & South Africa & Apricot & + & + & + \\
\hline ICMP 7492 & Sao Paulo, Brazil & Peach & + & + & - \\
\hline QDPI-JNG 1 & Queensland, Australia & Plum & + & + & + \\
\hline QDPI-JNG 2 & Queensland, Australia & Plum & + & + & + \\
\hline QDPI-JNG 3 & Queensland, Australia & Plum & + & + & - \\
\hline QDPI-JNG 4 & Queensland, Australia & Plum & + & + & - \\
\hline QDPI-JNG 5 & Queensland, Australia & Plum & + & + & + \\
\hline QDPI-JNG 6 & Queensland, Australia & Plum & + & + & + \\
\hline QDPI-JNG 7 & Victoria, Australia & Plum & + & + & + \\
\hline QDPI-JNG 8 & New South Wales, Australia & Nectarine & + & + & + \\
\hline QDPI-JNG 9 & Queensland, Australia & Plum & + & + & + \\
\hline QDPI-JNG 10 & Queensland, Australia & Plum & + & + & + \\
\hline QDPI-JNG 11 & Western Australia, Australia & Plum & + & + & - \\
\hline QDPI-JNG 12 & Queensland, Australia & Plum & + & + & + \\
\hline QDPI-JNG 13 & Queensland, Australia & Plum & + & + & + \\
\hline QDPI-JNG 14 & Queensland, Australia & Plum & + & + & + \\
\hline QDPI-JNG 15 & Victoria, Australia & Plum & + & + & + \\
\hline QDPI-JNG 16 & Victoria, Australia & Plum & + & + & + \\
\hline QDPI-JNG 17 & Queensland, Australia & Plum & + & + & + \\
\hline QDPI-JNG 18 & Victoria, Australia & Nectarine & + & + & + \\
\hline QDPI-JNG 19 & Queensland, Australia & Plum & + & + & + \\
\hline QDPI-JNG 20 & Queensland, Australia & Plum & + & + & + \\
\hline B0003 & Thulimbah, Queensland & Plum & + & + & + \\
\hline B0028 & Thulimbah, Queensland & Plum & + & + & + \\
\hline B0030 & The Summit, Queensland & Plum & + & + & + \\
\hline \multirow[t]{2}{*}{ B0144 } & Thulimbah, Queensland & Plum & + & + & + \\
\hline & & & & & on next page) \\
\hline
\end{tabular}


Differential screening was carried out by Southern blot hybridization. RsaI-digested tester and driver genomic DNA was digoxigenin (DIG)-11-dUTP labeled using the DIG High Prime DNA Labelling and Detection Starter Kit I (Roche Diagnostics GmbH, Mannheim, Germany) following the manufacturer's instructions. PCR products (150 ng) ranging in size from 800 to $1,300 \mathrm{bp}$ were transferred to positively charged nylon membranes (Roche Diagnostics $\mathrm{GmbH}$ ) under vacuum (Hoefer PR 648 slot blot manifold) and fixed to the membrane by UV cross-linking. Duplicate membranes were hybridized overnight to tester or driver DNA probes at $65^{\circ} \mathrm{C}$, as described in the DIG application manual (Roche Diagnostics $\mathrm{GmbH}$ ).

Clones showing differential or no hybridization to the driver DNA probe were sequenced by the Australian Genome Research Facility using M13 forward and reverse primers. The sequences were checked for homology to GenBank accessions using BlastN and BlastX nonredundant databases (http://www.ncbi.nlm.nih. gov/BLAST). Primer pair 29F/R was designed with the aid of Oligo Primer Analysis Software (version 6.71; Molecular Biology Insights).

Real-time PCR comparison with published $X$. arboricola pv. pruni primers. The real-time SYBR Green I primer pair 29F/R assay was set up in a 96-well plate with a $10-\mu$ l reaction mix per well containing a final concentration of $1 \times$ SYBR Green PCR Master Mix (Applied Biosystems, Foster City, CA), $0.2 \mu \mathrm{M}$ each primer (29F [5'-GTACCGCATTTCAGGCCGTCA-3'] and 29R [5'-AAGTAGCCAACGCGGAATTT-3']; GeneWorks, Adelaide, SA, Australia), bovine serum albumin at $1 \mathrm{mg} \mathrm{ml}^{-1}$, and $25 \mathrm{ng}$ of template DNA. The ABI 7900HT sequence detection system (Applied Biosystems) was used with the following cycling conditions: $95^{\circ} \mathrm{C}$ for $10 \mathrm{~min}$ and 45 cycles of $95^{\circ} \mathrm{C}$ for $30 \mathrm{~s}, 57^{\circ} \mathrm{C}$ for $30 \mathrm{~s}$, and $72^{\circ} \mathrm{C}$ for $30 \mathrm{~s}$. The dissociation curve for each product was determined using the following protocol: $95^{\circ} \mathrm{C}$ for $2 \mathrm{~min}, 60^{\circ} \mathrm{C}$ for $15 \mathrm{~s}$, and $95^{\circ} \mathrm{C}$ for $15 \mathrm{~s}$.

DNA from each of the bacterial strains described in Table 1 was used as template to compare the real-time assay with the $X$. arboricola pv. pruni diagnostic PCRs described by Zuli (32) and the Pagani (17). Both the Zuli (32) and Pagani (17) protocols were followed as described except for the use of AmpliTaq Gold at 0.02 $\mathrm{U}_{\mu 1^{-1}}$ and $1 \times$ GeneAmp PCR Buffer II in 25- $\mu$ l PCR reactions.

Sensitivity of the real-time PCR. A serial dilution series ranging from $4.5 \times 10^{8}$ to $4.5 \times 10^{-1} \mathrm{CFU} \mathrm{m} \mathrm{m}^{-1}$, as determined by plate counting, was prepared in sterile water from a 2-day-old $X$. arboricola pv. pruni strain ICMP 51 culture. A serial dilution series of

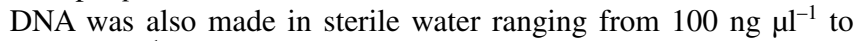
$0.01 \mathrm{pg}^{-1} \mathrm{l}^{-1}$. A $1-\mu \mathrm{l}$ volume of each dilution was used as template for PCR using the real-time SYBR Green I primer 29F/R assay as described above. Both experiments were repeated twice.

Field evaluation of real-time PCR specificity. Real-time PCR on mixed template. Asymptomatic twigs were collected from plum trees, which had previously shown symptoms of bacterial spot, on five occasions between 29 September and 25 November 2004 at the Applethorpe Research Station $\left(28^{\circ} 37^{\prime} 21.61^{\prime \prime} \mathrm{S}, 151^{\circ} 56^{\prime}\right.$ $\left.48.49^{\prime \prime} \mathrm{E}\right)$. Tissue was weighed and washed in up to $30 \mathrm{ml}$ of sterile water for a period of $5 \mathrm{~min}$. The wash was then serially diluted 10-fold to 1:10000 and a 100- $\mu$ l volume of each dilution

Table 1. (continued from preceding page)

\begin{tabular}{|c|c|c|c|c|c|}
\hline \multirow[b]{2}{*}{ Isolates $^{\mathbf{b}}$} & \multirow[b]{2}{*}{ Origin } & \multirow[b]{2}{*}{ Host plant $^{\mathrm{c}}$} & \multicolumn{3}{|c|}{ PCR amplification with primer pairs ${ }^{a}$} \\
\hline & & & 29F/R & Zuli & Pagani \\
\hline B1539 & Ballandean, Queensland & Plum & + & + & + \\
\hline B1540 & Ballandean, Queensland & Plum & + & + & + \\
\hline B1541 & Ballandean, Queensland & Plum & + & + & + \\
\hline B1542 & Ballandean, Queensland & Plum & + & + & + \\
\hline B1825 & Applethorpe, Queensland & Plum & + & + & + \\
\hline QDPI-16 & Australia & Plum & + & + & - \\
\hline QDPI-18 & Australia & Plum & + & + & - \\
\hline QDPI-20 & Australia & Plum & + & + & + \\
\hline CFBP 5577 & France & Peach & + & + & + \\
\hline Canker P11 C1 & Applethorpe, Queensland & Plum & + & + & + \\
\hline Canker P4 C2 & Applethorpe, Queensland & Plum & + & + & + \\
\hline Fruit E6 F2 & Applethorpe, Queensland & Plum & + & + & + \\
\hline Fruit L14 F2 & Applethorpe, Queensland & Plum & + & + & + \\
\hline Fruit F4 F1 & Applethorpe, Queensland & Plum & + & + & + \\
\hline Fruit L3 F1 & Applethorpe, Queensland & Plum & + & + & + \\
\hline Leaf E8 L3 & Applethorpe, Queensland & Plum & + & + & + \\
\hline Leaf F4 L2 & Applethorpe, Queensland & Plum & + & + & + \\
\hline \multicolumn{6}{|c|}{ X. arboricola pv. corylina } \\
\hline ICMP $5726^{\mathrm{T}}$ & United States & Filbert & - & + & - \\
\hline ICMP 449 & Oregon, United States & Hazelnut & - & + & - \\
\hline ACM 2135 & Victoria & Hazelnut & - & + & - \\
\hline ICMP 7081 & United Kingdom & Hazelnut & - & + & - \\
\hline ICMP 11956 & France & Hazelnut & - & + & + \\
\hline \multicolumn{6}{|c|}{ X. arboricola pv. juglandis } \\
\hline ICMP $35^{\mathrm{T}}$ & Mt. Albert, New Zealand & Walnut & - & - & - \\
\hline ICMP 34 & England, United Kingdom & Walnut & - & - & - \\
\hline ICMP 10865 & Valencia, Spain & Walnut & - & - & - \\
\hline ICMP 11829 & France & Walnut & - & + & + \\
\hline ICMP 11955 & Italy & Walnut & - & - & - \\
\hline \multicolumn{6}{|c|}{$X$. arboricola pv. celebensis } \\
\hline ICMP 1488 & Auckland, New Zealand & Banana & - & - & - \\
\hline \multicolumn{6}{|c|}{ X. arboricola pv. poinsettiicola } \\
\hline ICMP 6274 & Mt. Albert, New Zealand & Poinsettia & - & - & + \\
\hline ICMP 7180 & Mt. Albert, New Zealand & Poinsettia & - & - & + \\
\hline \multicolumn{6}{|c|}{ X. arboricola pv. populi } \\
\hline ICMP $8923^{\mathrm{T}}$ & Roggebotslusis, Netherlands & Euramerican poplars & - & - & - \\
\hline ICMP 9367 & New Zealand & Interamerican poplars & - & - & - \\
\hline ICMP 11965 & France & Necklace poplar & - & - & - \\
\hline ICMP 11974 & Italy & Euramerican poplars & - & - & - \\
\hline \multicolumn{6}{|c|}{$X$. arboricola pv. fragariae } \\
\hline LMG 19145 & Cesena, Italy & Strawberry & - & - & - \\
\hline
\end{tabular}


was spread onto agar plates containing GYCA medium in duplicate. Plates were incubated at $28 \pm 2{ }^{\circ} \mathrm{C}$ for 4 days. A loopful of growth representing all of the different bacterial colony forms present on each twig was added directly to extraction buffer (200 $\mathrm{mM}$ Tris- $\mathrm{HCl}$ [pH 7.5], $250 \mathrm{mM} \mathrm{NaCl}, 25 \mathrm{mM}$ EDTA, $0.5 \%$ sodium dodecyl sulfate, and $2 \%$ polyvinyl-pyrrolidone) and the DNA extracted as per the Llop et al. (13) protocol. DNA was quantified by visual comparison with Hyperladder I following gel

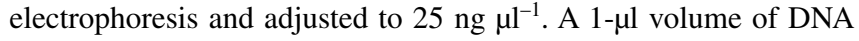
was added to the PCR mix for amplification with the real-time SYBR Green I primer pair 29F/R assay described above.

Real-time PCR on individual colony forms. During 2005, five 6year-old plum trees of the highly susceptible 'Friar' were chosen for study at the Applethorpe Research Station (26). Trees were growing in an open vase shape, had not been copper treated, and had previously shown bacterial spot symptoms. Sampling occurred on 12 occasions between 4 September and 27 November, between the state of plum "full bloom" (29) and the first observed appearance of bacterial spot fruit and leaf symptoms. During each sampling, an "epiphytic" sample consisting of a combination of fruit, leaves, and twigs was collected from each tree. Tissue was washed in a small volume of sterile water for $3 \mathrm{~min}$. The wash was then serially diluted and plated onto GYCA medium as described above. A selection of individual colonies representing each colony form present on the plate were placed directly into extraction buffer as described above. A 1- $\mu$ l volume of DNA was added to the PCR mix for amplification with the real-time SYBR Green I primer pair 29F/R assay described above.

Field evaluation of Bio-PCR. Experimental trial site. During the 2006-07 growing season, two trees from both the highly susceptible 'Laroda' and 'Friar' were chosen for study at the Applethorpe Research Station (26). The trees were 14 years old, had been trained in an open vase shape, had not been sprayed with copper, and had previously shown bacterial spot symptoms. Sampling occurred on nine occasions (5 to 9 days apart) between 4 September and 6 November 2006, between the period of plum full bloom (29) and the first observation of leaf and fruit symptoms on both cultivars for the growing season. Samples were bulked per cultivar and separated into three tissue types: "epiphytic," "asymptomatic leaf scars," and "cankers". The epiphytic sample was as described above. Both asymptomatic leaf scar and canker tissue came from twigs which had developed during the previous growing season. Asymptomatic leaf scars were defined as the bulbous area surrounding and including the leaf scar. The canker tissue included both the external and internal symptomatic tissues from the bacterial spot canker. For data analysis, sampling dates were defined as the number of weeks prior to the first observation of leaf and fruit symptoms, with the last sampling date being defined as the time when symptoms were observed for the first instance on both cultivars, indicated as week 0 . A weather monitoring station was positioned within the experimental site and collected temperature and rainfall data at 15 -min intervals.

Confirmation of $X$. arboricola pv. pruni isolation from plant tissue using Bio-PCR. For both asymptomatic leaf scars and canker tissue, whole twigs were surface sterilized in $75 \%$ ethanol for 2 min, washed for $5 \mathrm{~s}$ in sterile distilled water, and placed into $1 \%$ sodium hypochlorite for $3 \mathrm{~min}$, followed by three 5-s washes in sterile distilled water. Asymptomatic leaf scars and cankers were then excised from the twig with a flame-sterilized "v"-shaped linoleum cutting tool. The tissue was crushed with a hammer in a sterile petri dish between two sterile sheets of filter paper (Whatman No. 1), weighed, and resuspended in $10 \mathrm{ml}$ of sterile water. Each suspension was incubated for $1 \mathrm{~h}$ at $28^{\circ} \mathrm{C}$ with shaking on a rotary shaker at $200 \mathrm{rpm}$ (Bioline). For the epiphytic sample, twigs, leaves, and fruit were not surface sterilized and were only shaken for $3 \mathrm{~min}$. The suspensions were serially diluted 10 -fold up to a maximum dilution of $10^{-7}$. A $100-\mu$ l volume of each suspension was spread onto agar plates containing XPSM medium in triplicate for the undiluted suspension and three sequential dilutions between $10^{-1}$ and $10^{-7}$, chosen on the basis of results obtained during the previous week of the study. Plates were incubated at $28 \pm 2{ }^{\circ} \mathrm{C}$ for 6 days. Putative $X$. arboricola pv. pruni-like colonies from plates containing between 30 and 300 colonies were counted. Four individual putative $X$. arboricola pv. pruni-like colonies (shiny, convex, opaque, and grayish white in color) were isolated from the XPSM plates to confirm $X$. arboricola pv. pruni isolation. Two of the putative $X$. arboricola pv. pruni-like colonies were streaked onto GYCA agar and incubated at $28 \pm 2^{\circ} \mathrm{C}$ for 4 days to confirm characteristic $X$. arboricola pv. pruni colony phenotype (shiny, convex, and buttercup yellow with a butyrous consistency) on this medium. The other two putative $X$. arboricola pv. pruni-like colonies were placed into $100 \mu \mathrm{l}$ of sterile water and individually tested by PCR with the $X$. arboricola pv. pruni-specific real-time SYBR Green I primer pair 29F/R assay described above. Once $X$. arboricola pv. pruni isolation was confirmed, the number of CFU g $\mathrm{g}^{-1}$ of tissue was determined using the averaging colony count calculated from the triplicate plates for the dilution counted. The number of $\mathrm{CFU} \mathrm{g} \mathrm{g}^{-1}$ of tissue was transformed using $\log (1+\mathrm{CFU}) \mathrm{g}^{-1}$ of tissue fresh weight for graphical representation of the data.

\section{Results}

Development and specificity of primer pair 29F/R designed from DNA sequence obtained by SSH and its comparison with other published $X$. arboricola pv. pruni primers. A putative $X$.
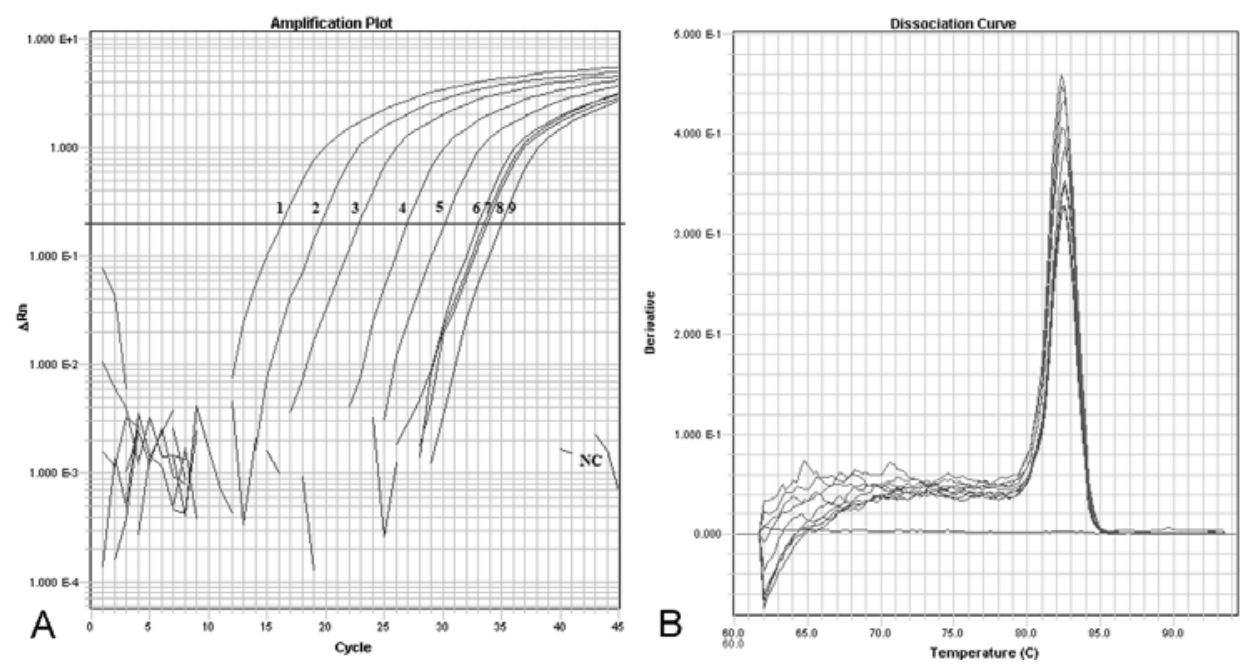

Fig. 1. Sensitivity of real-time SYBR Green I polymerase chain reaction (PCR) assay with primer pair 29F/R assessed by 10-fold serial dilutions of a cell suspension of Xanthomonas arboricola pv. pruni strain ICMP 51. A, Real-time amplification curve of different concentrations of DNA and a threshold set at 0.2. Line 1-9: 10-fold dilution of $X$. arboricola pv. pruni strain ICMP 51 cell suspension $\left(4.5 \times 10^{8}\right.$ to $\left.4.5 \mathrm{CFU} \mathrm{ml}^{-1}\right)$; NC: PCR-negative control containing no DNA. B, Dissociation curve analysis. 
arboricola pv. pruni-specific subtracted DNA library was obtained using SSH. Southern blot analysis identified 29 putative $X$. arboricola pv. pruni-specific subtracted DNA clones which exhibited no or differential hybridization to driver (X. arboricola pv. corylina) genomic DNA. DNA from all of these clones was sequenced and analyzed by comparison with the GenBank database (2). Primer pair 29F/R was designed from a DNA sequence which did not show similarity to sequences deposited in GenBank. The sequence has been deposited in GenBank as accession number HN268887. The real-time SYBR Green I primer pair 29F/R assay amplified DNA from all of the $X$. arboricola pv. pruni strains tested and did not amplify any of the other $X$. arboricola pathovars (Table 1). When the PCR products were analyzed on an agarose gel, the expected amplicon size of $344 \mathrm{bp}$ was evident for all the $X$. arboricola pv. pruni strains (data not shown). The dissociation curve showed that the $X$. arboricola pv. pruni amplification product had a melting temperature of $82^{\circ} \mathrm{C}$ (data not shown).

The detection limit of this real-time PCR assay was determined using dilution series for both an X. arboricola pv. pruni bacterial cell suspension and purified DNA. Template was amplified in all dilutions of $X$. arboricola pv. pruni bacterial cells, with a lower limit of $4.5 \mathrm{CFU} \mathrm{m}{ }^{-1}$ detected (Fig. 1). However, between $4.5 \times$

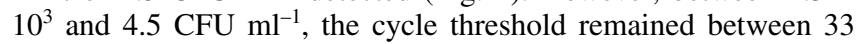
and 35 cycles (Fig. 1A). The limit of detection for X. arboricola pv. pruni genomic DNA was $0.1 \mathrm{pg}$ per reaction (data not shown). All $X$. arboricola pv. pruni amplicons yielded a single strong peak at $82^{\circ} \mathrm{C}$ on the dissociation curve (Fig. 1B).

The primer pair designed by Zuli (32) amplified DNA from all of the $X$. arboricola pv. pruni strains examined, yielding the expected 180-bp amplicon (data not shown); however, DNA from all of the $X$. arboricola pv. corylina strains also yielded the 180-bp amplicon, as did DNA from $X$. arboricola pv. juglandis strain ICMP 11829 (Table 1).

The Pagani (17) primers yielded the expected 950-bp amplicon for DNA from $X$. arboricola pv. pruni isolates (data not shown). However, 8 of the $44 X$. arboricola pv. pruni strains could not be amplified by this primer pair (Table 1). DNA from $X$. arboricola pv. corylina strain ICMP 11956, X. arboricola pv. juglandis strain ICMP 11829 , and both of the $X$. arboricola pv. poinsettiicola isolates yielded amplicons of a size similar to that of the $X$. arboricola pv. pruni isolates (data not shown).

Field evaluation of real-time PCR. Washings plated onto GYCA medium from the surface of asymptomatic twigs showed evidence of a range of bacteria present at the time of sampling.

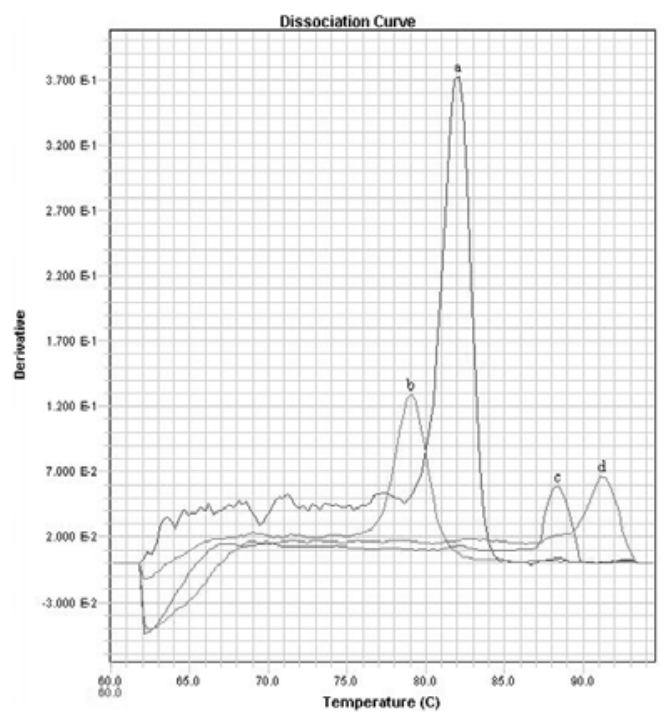

Fig. 2. Dissociation curve of polymerase chain reaction (PCR) amplification products from isolates of Xanthomonas arboricola pv. pruni (a), golden yellow colony form (b), white/yellow colony form (c), and pale yellow colony form (d) from glucose-yeast-calcium-carbonate agar using the real-time SYBR Green I PCR primer pair 29F/R assay.
However, $X$. arboricola pv. pruni-like colony forms were always present on plates at each sampling. The real-time SYBR Green 1 primer pair $29 \mathrm{~F} / \mathrm{R}$ assay amplified $X$. arboricola pv. pruni template from within mixed template at each sampling with products demonstrating a melting temperature of $82^{\circ} \mathrm{C}$ (data not shown).

In total, 143 single bacterial colonies were isolated from washings containing the epiphytic bacterial populations present on the surface of plum twigs, leaves, and fruit. In all, 87 colonies showed the typical $X$. arboricola pv. pruni phenotype on GYCA agar and produced amplification products which had a melting temperature of $82^{\circ} \mathrm{C}$ using the real-time SYBR Green 1 primer pair $29 \mathrm{~F} / \mathrm{R}$ assay (data not shown). The remaining 56 colonies were not phenotypically $X$. arboricola pv. pruni-like on GYCA agar and, although no attempt was made to identify these bacteria, 14 visually distinct colony phenotypes were evident from this collection. Of these colony types, 11 were not amplifiable by the real-time assay; however, 3 colony phenotypes (golden yellow, white/yellow, and pale yellow colony forms) produced late amplification reactions ( $>35$ cycles at a threshold of 0.2 ) and their products had melting temperatures of 79,88 , and $91^{\circ} \mathrm{C}$, respectively (Fig. 2).

Bio-PCR evaluation. The Bio-PCR protocol confirmed the isolation of epiphytic $X$. arboricola pv. pruni and X. arboricola pv. pruni associated with asymptomatic leaf scar and canker tissue. Occasionally, colonies not phenotypically $X$. arboricola pv. prunilike grew on XPSM agar; however, these colony forms were low in number and did not interfere with plate counts. $X$. arboricola pv. pruni-like colonies from XPSM plates were confirmed as being $X$. arboricola pv. pruni because they always grew with the anticipated phenotype on GYCA agar, and the PCR amplification products in the real-time SYBR Green I assay for each colony had a melting temperature of $82^{\circ} \mathrm{C}$ (data not shown).

The first leaf and fruit bacterial spot symptoms were observed on both plum cultivars 9 weeks into the trial, on 6 November 2006, and this was defined as week 0 . Development of $X$. arboricola pv. pruni populations associated with asymptomatic leaf scars, cankers, and epiphytic populations over these 9 weeks are shown in Figures 3, 4, and 5, respectively. X. arboricola pv. pruni populations associated with asymptomatic leaf scars ranged from $2.58 \times$ $10^{4}$ to $1.06 \times 10^{9} \mathrm{CFU} \mathrm{g}^{-1}$ of tissue in Friar and $2.47 \times 10^{3}$ to 4.36 $\times 10^{11} \mathrm{CFU} \mathrm{g}^{-1}$ of tissue in Laroda over this time frame (Fig. 3). A sudden decrease in $X$. arboricola pv. pruni population size by more than five orders of magnitude, 7 weeks prior to leaf and fruit symptoms, was evident for both plum cultivars (Fig. 3). The average weekly temperature recorded at the trial site also dropped during this week, potentially suggesting a link with the $X$. arboricola $\mathrm{pv}$. pruni population trend (Fig. 3 ).

Overall, the $X$. arboricola pv. pruni populations increased within cankers in both plum cultivars prior to the first observation of leaf and fruit symptoms during the 2006-07 growing season (Fig. 4). Interestingly, $X$. arboricola pv. pruni populations suddenly

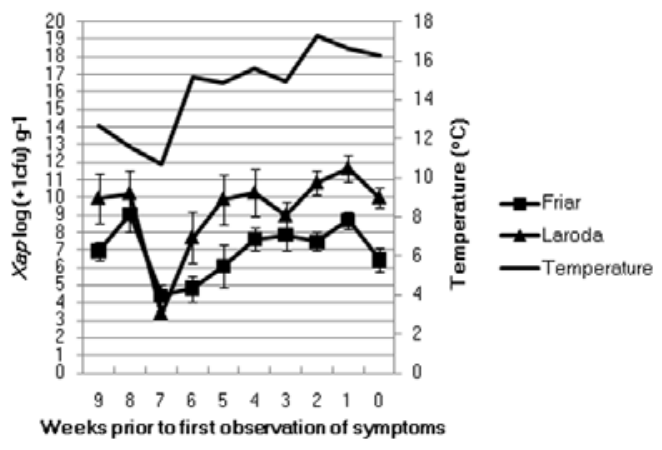

Fig. 3. Numbers of Xanthomonas arboricola pv. pruni log $(1+\mathrm{CFU}) \mathrm{g}^{-1}$ asymptomatic leaf scar tissue fresh weight over the 9 weeks prior to the first observation (week $0=6$ November 2006) of leaf and fruit symptoms on 'Friar' and 'Laroda' plum during the 2006 season compared with the average weekly temperature during this time. Values are means of counts of CFU on three plates for each plum cultivar and the standard error (black bar) is indicated for each sample. 
dropped by seven orders of magnitude to below detectable levels 8 weeks prior to the observation of symptoms on Friar and five orders of magnitude to below detectable levels 7 weeks prior to the observation of symptoms on Laroda (Fig. 4). Between weeks nine and seven, there was a drop in average weekly temperature at the trial site, which may have influenced a drop in $X$. arboricola $\mathrm{pv}$. pruni populations at this site in both plum cultivars. $X$. arboricola pv. pruni numbers increased to $5.67 \times 10^{8} \mathrm{CFU} \mathrm{\textrm {g } ^ { - 1 }}$ of tissue in Friar 5 weeks prior to the first symptoms and $4.14 \times 10^{8} \mathrm{CFU} \mathrm{g}{ }^{-1}$ of tissue in Laroda 2 weeks prior to appearance of the first symptoms (Fig. 4).

Epiphytic $X$. arboricola pv. pruni populations generally increased steadily over the 9-week period (Fig. 5). However, the epiphytic $X$. arboricola pv. pruni population on Laroda was at least two orders of magnitude higher than on Friar for the majority of the sampling dates (Fig. 5). The highest epiphytic X. arboricola pv. pruni population measured was $6.27 \times 10^{7} \mathrm{CFU} \mathrm{g}^{-1}$ of tissue on Friar and $5.52 \times 10^{9} \mathrm{CFU} \mathrm{g^{-1 }}$ of tissue on Laroda (Fig. 5). This peak in the $X$. arboricola pv. pruni population associated with Laroda may be related to an increase in temperature at this time (Fig. 5). No correlations between rainfall and $X$. arboricola pv. pruni populations in any of the tissues examined were evident (data not shown).

\section{Discussion}

$X$. arboricola pv. pruni has recently been reported on apricot and plum in Switzerland (20) and almond in Europe (18). To confirm $X$. arboricola pv. pruni identification, these authors conducted a range of tests on symptomatic tissue, including the molecularbased $X$. arboricola pv. pruni-specific PCR designed by Pagani

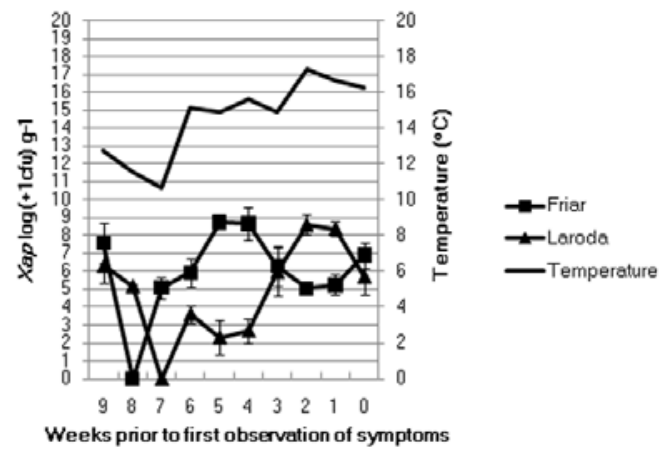

Fig. 4. Numbers of Xanthomonas arboricola pv. pruni $\log (1+\mathrm{CFU}) \mathrm{g}^{-1}$ canker tissue fresh weight over the 9 weeks prior to the first observation (week $0=6$ November 2006) of leaf and fruit symptoms on 'Friar' and 'Laroda' plum during the 2006 season compared with the average weekly temperature during this time. Values are means of counts of CFU on three plates for each plum cultivar and the standard error (black bar) is indicated for each sample.

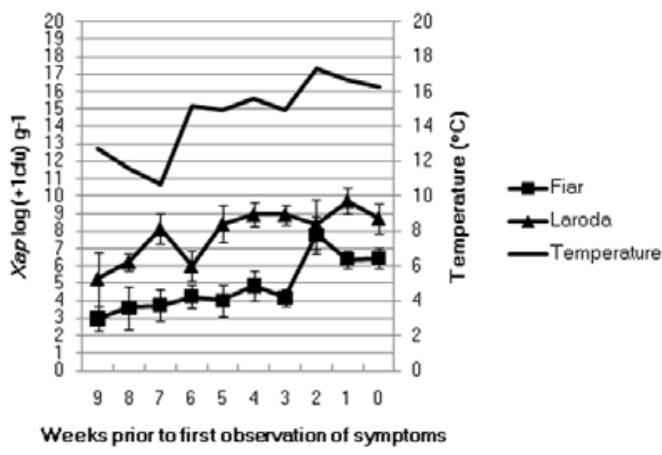

Fig. 5. Numbers of epiphytic Xanthomonas arboricola pv. pruni log (1+CFU) $g^{-1}$ tissue fresh weight over the 9 weeks prior to the first observation (week $0=6$ November 2006) of leaf and fruit symptoms on 'Friar' and 'Laroda' plum during the 2006 season compared with the average weekly temperature during this time. Values are means of counts of CFU on three plates for each plum cultivar and the standard error (black bar) is indicated for each sample.
(17). Although the Pagani (17) primer pair amplified X. arboricola pv. pruni DNA in all of the infected tissues examined in these two instances, testing of this primer pair during the experiments outlined within this article shows a lack of primer binding in some $X$. arboricola pv. pruni isolates and cross-specificity with other $X$. arboricola pathovars. Therefore, the requirement of an X. arboricola pv. pruni-specific molecular-based test is essential for a reliable diagnosis of new outbreaks of this pathogen in the future.

Sources of $X$. arboricola pv. pruni inoculum within plum trees in Applethorpe, Queensland appear to include epiphytic X. arboricola pv. pruni as well as $X$. arboricola pv. pruni associated with asymptomatic leaf scars and cankers on plums. X. arboricola pv. pruni associated with each of these tissue types has been previously demonstrated but a study examining all of these tissue types at the same time has not been previously attempted $(25,30,31)$. The $X$. arboricola pv. pruni populations associated with these sites and the influence weather has on these populations warrants further investigation using larger sample numbers over a greater time period. This type of study is now possible with the availability of the $X$. arboricola pv. pruni-specific Bio-PCR protocol. Alternatively, to speed up the assay, the PCR component of the method could potentially be utilized as a quantitative real-time PCR assay using fresh tissue, if this tissue had not been previously treated with copper. However, the limit of detection of the assay will be significantly higher due to the clustering of cycle thresholds for lower CFU levels, which is not an uncommon phenomenon for real-time PCR assays $(10,15)$.

Spurious nonspecific backgrounds showing up as late-cycle amplifications is not unusual with SYBR Green real-time PCR (19). Melt-curve analysis is routinely used in this type of assay (24). Non- $X$. arboricola pv. pruni PCR products are clearly differentiated from true $X$. arboricola pv. pruni amplification products using the melt-curve analysis step built into the real-time SYBR Green I primer pair $29 \mathrm{~F} / \mathrm{R}$ assay and, therefore, the assay appears to be specific for the detection of $X$. arboricola pv. pruni. Further validation of this assay is described in the thesis by Ballard (2). In Table 1 , there is a set of eight canker, fruit, and leaf bacterial spot symptom isolates which were PCR amplified by the real-time SYBR Green I primer pair 29F/R assay and Zuli (32) and Pagani (17) protocols. These eight isolates were also examined with the BIOLOG GN microplate system, 16S rRNA gene sequencing, and a detached leaf assay, providing further support of the specificity of primer pair $29 \mathrm{~F} / \mathrm{R}$.

The aim of this study was to develop a Bio-PCR protocol for the detection of $X$. arboricola pv. pruni. The SSH method used to obtain tester-specific DNA from a pathovar type strain of $X$. arboricola pv. pruni using $X$. arboricola pv. corylina as the driver proved a successful approach. The detection of epiphytic $X$. arboricola pv. pruni and $X$. arboricola pv. pruni populations associated with asymptomatic leaf scars and cankers over a 9-week period prior to the first observation of leaf and fruit symptoms in the orchard provided proof-of-concept for using the Bio-PCR protocol in future epidemiological studies. A greater understanding of the life cycle of this pathogen and an effective method for the early detection of $X$. arboricola pv. pruni may help in improving control strategies for bacterial spot in the future.

\section{Acknowledgments}

This work was supported by grants from the Queensland State Government Department of Employment, Economic Development and Innovation, Queensland Fruit and Vegetable Growers, and The University of Queensland.

\section{Literature Cited}

1. Akopyants, N. S., Fradkov, A., Diatchenko, L., Hill, J. E., Siebert, P. D., Lukyanov, S. A., Sverdlov, E. D., and Berg, D. E. 1998. PCR-based subtractive hybridization and differences in gene content among strains of Helicobacter pylori. Proc. Natl. Acad. Sci. USA 95:13108-13113.

2. Ballard, E. L. 2008. Epidemiology of bacterial spot in plums at Applethorpe, Queensland. PhD thesis, The University of Queensland, Brisbane QLD, Australia.

3. Bauer, A. P., Dieckmann, S. M., Ludwig, W., and Schleifer, K. H. 2007. Rapid identification of Escherichia coli safety and laboratory strain lineages 
based on mulitplex-PCR. FEMS Microbiol. Lett. 269:36-40.

4. Diatchenko, L., Lau, Y. C., Campbell, A. P., Chenchik, A., Maqadam, F., Huang, B., Luykyanov, S., Lukyanov, K. A., Gurskaya, N. G., Sverdlov, E. D., and Siebert, P. D. 1996. Suppression subtractive hybridization: a method for generating differentially regulated or tissue-specific cDNA probes and libraries. Proc. Natl. Acad. Sci. USA 93:6025-6030.

5. Garcin, A. 2000. Bacterial spot on stone fruit trees: a recent pathogen in France. Infos Ctifl 165:45-47.

6. Guo, L. H., Shi, J. N., Zhang, Y. U., Lui, X. C., Duan, J., and Wei, S. 2006. Identification of genetic differences between two clinical isolates of Streptococcus mutans by suppression subtractive hybridization. Oral Microbiol. Immunol. 21:372-380.

7. Hadas, R., Kritzman, G., Klietman, F., Gefen, T., and Manulis, S. 2005. Comparison of extraction procedures and determination of the detection threshold for Clavibacter michiganensis ssp. michiganensis in tomato seeds. Plant Pathol. 54:643-649.

8. Han, F. C., Gong, M., Ng, H. C., and Ho, B. 2003. Identification of H. phylori strain specific DNA sequences between two clinical isolates from NUD and gastric ulcer by SSH. World J. Gastroenterol. 9:1747-1751.

9. Hartung, J. S., Pruvost, O. P., Villemot, I., and Alvarez, A. 1996. Rapid and sensitive colorimetric detection of Xanthomonas axonopodis pv. citri by immunocapture and a nested-polymerase chain reaction assay. Phytopathology 86:95-101.

10. Hird, H., Lloyd, J., Goodier, R., Brown, J., and Reece, P. 2003. Detection of peanut using real-time polymerase chain reaction. Eur. Food Res. Technol. 217:265-268.

11. Jami, F., Kazempour, M. N., Elahinia, S. A., and Khodakaramian, G. 2005. First report of Xanthomonas arboricola pv. pruni on stone fruit trees in Iran. J. Phytopathol. 153:371-372.

12. Kuflu, K. M., and Cuppels, D. A. 1997. Development of a diagnostic DNA probe for Xanthomonads causing bacterial spot of pepper and tomatoes. Appl. Environ. Microbiol. 63:4462-4470.

13. Llop, P., Caruso, P., Cubero, J., Morente, C., and Lopez, M. 1999. A simple extraction procedure for efficient routine detection of pathogenic bacteria in plant material by polymerase chain reaction. J. Microbiol. Methods 37:2331 .

14. Manulis, S., Chalupowicz, L., Dror, O., and Kleitman, F. 2002. Molecular diagnostic procedures for production of pathogen-free propagation material. Pest Manage. Sci. 58:1126-1131.

15. Morrison, T. B., Weis, J. J., and Wittwer, C. T. 1998. Quantification of lowcopy transcripts by continuous SYBR Green I monitoring during amplification. BioTechniques 24:954-962.

16. OEPP/EPPO. 2006. Xanthomonas arboricola pv. pruni. EPPO Bull. 36:129-133.

17. Pagani, M. C. 2004. An ABC transporter protein and molecular diagnoses of Xanthomonas arboricola pv. pruni causing bacterial spot of stone fruits.
Ph.D. thesis, North Carolina State University, Raleigh.

18. Palacio-Bielsa, A., Roselló, M., Cambra, M. A., and López, M. M. 2010 First report on almond in Europe of bacterial spot disease of stone fruits caused by Xanthomonas arboricola pv. pruni. Plant Dis. 94:786-786.

19. Parida, M. M. 2008. Rapid and real-time detection technologies for emerging viruses of biomedical importance. J. Biosci. 33:617-628.

20. Pothier, J. F., Pelludat, C., Bunter, M., Genini, M., Vogelsanger, J., and Duffy, B. 2010. First report of the quarantine pathogen Xanthomonas arboricola pv. pruni on apricot and plum in Switzerland. Plant Pathol. 59:404-404.

21. Ritchie, D. F. 1995. Bacterial spot. in: Compendium of Stone Fruit Diseases. J. M. Ogawa, E. I. Zehr, G. W. Bird, D. F. Ritchie, K. Uriu, and J. K. Uyemoto, eds. The American Phytopathological Society, St. Paul, MN.

22. Sakthivel, N., Mortensen, C. N., and Mathur, S. B. 2001. Detection of Xanthomonas oryzae pv. oryzae in artificially inoculated and naturally infected rice seeds and plants by molecular techniques. Appl. Microbiol. Biotechnol. 56:435-441.

23. Schaad, N. W., Cheong, S. S., Tamaki, S., Haatziloukas, E., and Panopoulos, N. J. 1995. A combined biological and enzymatic amplification (BIOPCR) technique to detect Pseudomonas syringae pv. phaseolicola in bean seed extracts. Phytopathology 85:243-248.

24. Scipioni, A., Mauroy, A., Ziant, D., Saegerman, C., and Thiry, E. 2008. A SYBR green RT-PCR assay in single tube to detect human and bovine noroviruses and control for inhibition. Virol. J. 5:94.

25. Shepard, D. P., and Zehr, E. I. 1994. Epiphytic persistence of Xanthomonas campestris pv. pruni on peach and plum. Plant Dis. 78:627-629.

26. Topp, B. L., Heaton, J. B., Russell, D. M., and Mayer, R. 1989. Field susceptibility of Japanese-type plums to Xanthomonas campestris pv. pruni. Aust. J. Exp. Agric. 29:905-909.

27. Triplett, L. R., Zhao, Y., and Sundin, G. W. 2006. Genetic differences between blight-causing Erwinia species with differing host specificities, identified by suppression subtractive hybridization. Appl. Environ. Microbiol. 72:7359-7364

28. Vauterin, L., Hoste, K., Kersters, K., and Swings, J. 1995. Reclassification of Xanthomonas. Int. J. Syst. Bacteriol. 45:474-489.

29. Vock, N. 1998. Low Chill Stonefruit Information Kit. The State of Queensland, Department of Primary Industries, Nambour, Queensland, Australia.

30. Zaccardelli, M., Consiglio, M. F., and Mazzucchi, U. 1995. Detection of Xanthomonas campestris pv. pruni in symptomless peach trees in winter. Phytopathol. Mediterr. 34:199-203.

31. Zaccardelli, M., Malaguti, S., and Bazzi, C. 1998. Biological and epidemiological aspects of Xanthomonas arboricola pv. pruni on peach in Italy. J. Plant Pathol. 80:125-132.

32. Zuli, N. 2003. Molecular detection and diversity of Xanthomonas arboricola pv. pruni. Honors thesis, The University of Queensland, Brisbane, Australia. 